ISSN 1392-3196 / e-ISSN 2335-8947

Zemdirbyste-Agriculture, vol. 102, No. 3 (2015), p. 351-358

DOI $10.13080 / \mathrm{z}-\mathrm{a} .2015 .102 .045$

\title{
The effect of wheat bread contamination by the Bacillus genus bacteria on the quality and safety of bread
}

\author{
Lina VAIČIULYTĖ-FUNK ${ }^{1}$, Renata ŽVIRDAUSKIENE' ${ }^{1,2}$, Joana ŠALOMSKIENË ${ }^{1}$, \\ Antanas ŠARKINAS ${ }^{1}$ \\ ${ }^{1}$ Food Institute, Kaunas University of Technology \\ Taikos 92, Kaunas, Lithuania \\ E-mail: renata.zvirdauskiene@ktu.lt \\ ${ }^{2}$ Institute of Agriculture, Lithuanian Research Centre for Agriculture and Forestry \\ Instituto 1, Akademija, Kèdainiai distr., Lithuania
}

\begin{abstract}
The aim of the study was to determine the level of contamination of white bread by aerobic spore-forming bacteria that may cause the ropiness and to evaluate the antimicrobial activity of lactic acid bacteria against aerobic sporeforming bacteria during the storage of wheat bread at different temperatures. The contamination of dough samples by aerobic spore-forming bacteria did not affect the quality of bread in the initial storage phase $(6-16 \mathrm{~h}$ after baking). The critical Bacillus subtilis subsp. spizizenii ATCC 6633 levels that cause ropiness in baked bread were determined: $7.8 \times 10^{6} \mathrm{CFU}$ (colony forming units) $\mathrm{g}^{-1}$ after storage of samples for 3 days at $2 \pm 2^{\circ} \mathrm{C}, 1.3 \times 10^{6} \mathrm{CFU}$ $\mathrm{g}^{-1}$ after storage of samples for 3 days at $18 \pm 2{ }^{\circ} \mathrm{C}$ and $6.0 \times 10^{6} \mathrm{CFU} \mathrm{g}{ }^{-1}$ after storage of samples for 1 day at 30 $\pm 2{ }^{\circ} \mathrm{C}$ temperature. It was determined that contamination of dough by aerobic spore-forming bacteria should not exceed $1.0 \times 10^{3} \mathrm{CFU} \mathrm{g} \mathrm{g}^{-1}$. The evaluation of antimicrobial activities of lactic acid bacteria from Lactococcus and Lactobacillus genera against aerobic spore-forming bacteria was performed using an agar well diffusion method. In wheat bread, that had been fermented with Lactobacillus delbrueckii subsp. bulgaricus 148/3, L. acidophilus 336 and L. casei subsp. casei, the antimicrobial effects were observed for up to 3 days of storage at 18 and $30^{\circ} \mathrm{C}$ temperature. Weak signs of ropiness spoilage (sweet rope odour, discoloration of the crumb) were observed during the storage of the bread samples at $18 \pm 2^{\circ} \mathrm{C}$ for 5 days $\left(1.7 \times 10^{2} \mathrm{CFU} \mathrm{g}^{-1}\right)$ and at $30 \pm 2^{\circ} \mathrm{C}$ for 3 and 5 days $(1.5$ $\times 10^{2} \mathrm{CFU} \mathrm{g}^{-1}$ ).
\end{abstract}

Key words: Bacillus subtilis, lactic acid bacteria, ropiness, wheat bread.

\section{Introduction}

Bacillus are abundant in various ecological niches: soil, water, insect and animal feces (Heyndrickx, 2011; Logan, Halket, 2011; Zhang et al., 2014). Harvested cereal grains also contain Bacillus spores (Needham et al., 2005; Fangio et al., 2010; Sakalauskas et al., 2014) as a result of processing or post processing contamination. These are mostly distributed on the surface of the grain. The dominant infective species usually are Bacillus subtilis (Voysey, 1989; Rosenkvist, Hansen, 1995), but the spores of $B$. licheniformis, B. megaterium and $B$. cereus may also be infective (Voysey, Hammond, 1993; Blackburn, 2006; Brul et al., 2011). Endospores of Bacillus are highly resistant to destruction during storage and thus they may survive in a dormant state and be transferred to processed products where they could become a problem. Previous studies (Sorokulova et al., 2003; Iurlina et al., 2006; Aydin et al., 2009) indicated that all types of wheat flour were contaminated with Bacillus spores. The incidence of wheat bread spoilage caused by Bacillus has increased presumably because more bread is produced without preservatives and with addition of raw materials such as bran and seeds. Ropiness, which is the most important spoilage of bread after mouldiness, occurs particularly in summer under warm and humid conditions and is mainly caused by $B$. subtilis. The dominance of B. subtilis in bread could be explained by the high heat resistance of this species - some spores may survive during the baking process, because the maximum temperature during baking in the center of loaf is $97^{\circ} \mathrm{C}$ to $100^{\circ} \mathrm{C}$ for a few minutes (Setlow, 2005). Surviving spores germinate if conditions are favourable; their vegetative cells multiply by decomposing proteins and carbohydrates of bread crumb, turning the bread pulp into a sticky, slimy, and foul smelling mass. This defect is characterized by an unpleasant sweet, musty smell of rotting pineapples (Mentes et al., 2007; Valerio et al., 2008; Kornacki, 2010). First signs of ropiness appear after 10-20 hours after baking. The colour of the bread loaf changes, it becomes soft and sticky, in later stages the bread crumb becomes more viscous. Bread texture deteriorates due to proteolytic and amylolytic enzymes secreted by B. subtilis (Sorokulova et al., 2003; Mentes et al., 2007; Valerio et al., 2008; Kornacki, 2010). The growth of $B$. subtilis is partially inhibited by a low water 
activity and low $\mathrm{pH}$ in the bread pulp; however, under favourable development conditions; higher amounts of spores outgrow into vegetative cells and cause ropiness spoilage. Bread defects can cause huge economic losses for bakery industry (Thompson et al., 1998; Dewettinck et al., 2008). In order to prevent the development of ropiness defect in wheat bread, it is necessary to determine what level of bread contamination by aerobic spore-forming bacteria can cause the defect of ropiness, and what impact in this regard could have the duration of bread storage and temperature.

Lactic acid bacteria are widely used in the production of fermented foods as starter cultures. These bacteria are industrially important organisms and play an important role in food and feed fermentation and preservation either as the natural microflora or as starter cultures added under controlled conditions. Species used for food fermentation belong to the genera Lactococcus, Streptococcus, Pediococcus, Leuconostoc and Lactobacillus. Lactic acid bacteria have a long history of use in a variety of cereal fermentations, especially in the manufacture of baked goods (Hansen, 2002; Gobbetti et al., 2005).

The preservative action of starter cultures in food and beverage systems is attributed to the combined action of a range of antimicrobial metabolites produced during the fermentation process (Caplice, Fitzgerald, 1999; Denkova et al., 2014). Lactic acid is the dominant metabolite of lactic fermentation. The primary antimicrobial compounds produced by sourdough lactic acid bacteria are lactic and acetic acid, diacetyl, acetaldehyde, hydrogen peroxide, carbon dioxide and bacteriocins (Piard, Desmazeaud, 1992; Coloretti et al., 2008; Hladíková et al., 2012). Organic acids are generally thought to exert their antimicrobial effect by interfering with the maintenance of cell membrane potential, inhibiting active transport, reducing intracellular $\mathrm{pH}$ and inhibiting a variety of metabolic functions (Ross et al., 2002). Bacteriocins produced by lactic acid bacteria are of great interest to the food fermentation industry as natural preservatives because of their ability to inhibit the growth of many food spoilage and pathogenic bacteria (Bredholt et al., 2001; McAuliffe et al., 2001).

The aim of the study was to determine the level of contamination of white bread by aerobic sporeforming bacteria that may cause the ropiness and to evaluate the antimicrobial activity of lactic acid bacteria against aerobic spore-forming bacteria during the storage of baked bread at different temperatures.

\section{Materials and methods}

Subjects of the research. The subject of the research was the wheat bread contaminated using the reference strain Bacillus subtilis subsp. spizizenii ATCC 6633. Lactic acid bacteria: Lactobacillus delbrueckii subsp. bulgaricus 140/3, L. acidophilus 336, L. casei subsp. casei, Lactococcus lactis subsp. lactis 140/3, Lactobacillus bifidum, L. helveticus, L. plantarum and L. brevis taken from the collection of microorganisms of Food Institute of Kaunas University of Technology were used for the examination of the antimicrobial activity. The research was conducted during 2012-2014 at the Food Institute of Kaunas University of Technology.

Preparation of spore suspension. Spore suspension was prepared from the reference strain
B. subtilis subsp. spizizenii ATCC 6633. The culture was grown at $37^{\circ} \mathrm{C}$ on agar slants, using PCA (plate count agar) medium ("Liofilchem", Italy), then washed off from the agar with sterile saline $(0.85 \% \mathrm{NaCl})$ solution. For contamination of bread dough, three different concentrations of spore suspensions were prepared: 1.4 $\times 10^{4}(\mathrm{~T}-1), 2.8 \times 10^{6}(\mathrm{~T}-2)$ and $1.0 \times 10^{8}(\mathrm{~T}-3) \mathrm{CFU}$ (colony forming units) $\mathrm{ml}^{-1}$. For the determination of antimicrobial activity of lactic acid bacteria strains, the density of cell suspension was adjusted according to McFarland standard No. 0.5 (Cavalieri et al., 2005).

Contamination ofbreadbyaerobicspore-forming bacteria. Samples of bread dough were contaminated by adding the spore suspension: 1) to the dough during mixing for $10 \mathrm{~min}$, then the dough was kneaded for $5 \mathrm{~min}$; 2) to the dry mixture of bread components, then the dough was mixed for $15 \mathrm{~min} ; 3$ ) to a liquid dough phase, then the dough was mixed for $15 \mathrm{~min}$. In all the cases, the spore suspensions were dosed at $10 \mathrm{ml}$ to each bread dough sample $(370 \mathrm{~g})$. While assessing the homogeneity of contamination of the samples by spores, the number of aerobic spore-forming bacteria was determined in four samples taken from the different points of the shaped bread dough. For contamination of bread dough by aerobic spore-forming bacteria (to get bread ropiness spoilage), the spore suspensions (three different concentrations) were dosed at 4,8 and $12 \mathrm{ml}$ for bread dough samples (370 g), and during dough preparation, to the liquid phase. For experiments, bread products were wrapped into parchment and nutritional (polypropylene) film, and stored for 5 days at $2 \pm 2,18 \pm 2$ and $30 \pm 2{ }^{\circ} \mathrm{C}$. While storing, the occurrence of ropiness spoilage was observed every day, and the aerobic spore-forming bacteria count was determined by plating into Petri dishes.

Wheat bread preparation techniques. The recipe of wheat bread is provided in Table 1 .

Table 1. Wheat bread recipe

\begin{tabular}{cc}
\hline Ingredients & Amount g \\
\hline Wheat flour, 812 D type & 200.0 \\
Vegetable oil & 30.0 \\
Sugar & 40.0 \\
Pressed yeasts & 20.0 \\
Salt & 2.0 \\
Water & 206.0 \\
\hline
\end{tabular}

Description of the technological process. The dough was prepared by a single-phase method, with $48.5 \%$ moisture content. All the ingredients of the recipe were mixed until homogeneous consistency for $15 \mathrm{~min}$ ( 5 min slowly and 10 min fast) in a sterilized spiral mixer Metos SP-100A/NH-B (Metos Manufacturing, Finland). The kneaded dough was matured at $33-35^{\circ} \mathrm{C}$ for $1.5 \mathrm{~h}$. The acidity of the fermented and matured dough was $5.0-5.5^{\circ} \mathrm{N}$. The initial rising of dough semi-products was performed at $22-24^{\circ} \mathrm{C}$ for $15-17 \mathrm{~min}$. The dough samples were shaped manually. For experimental baking, hearth bread was prepared. The prepared dough was divided and risen in the shape forms. The duration of the last rising was $35-45 \mathrm{~min}$, temperature $-33-35^{\circ} \mathrm{C}$, relative humidity $-75-80 \%$. The baking time was $20-25 \mathrm{~min}$ at $220^{\circ} \mathrm{C}$. The baked bread was cooled to the room temperature. The quality characteristics for bread met the general requirements of the standard LST 1129:2003 Bread. General requirements. 
Technological characteristics of bread quality. Bread crumb moisture content was determined by drying of a crushed sample at $130 \pm 2{ }^{\circ} \mathrm{C}$ (LST 1492:2013 Bakery goods - Methods for determination of moisture content). Bread acidity was measured by titration of the sample by a $0.1 \mathrm{~mol} \mathrm{l}^{-1} \mathrm{NaOH}$ solution (LST 1553:1998 Bakery goods and confectionery. Methods for determination of acidity and alkalinity). The bread porosity index was determined by using the Žuravliov equipment according to the standard LST 1442:1996 Bread, rolls and buns. Determination of porosity.

The antimicrobial activity of lactic acid bacteria strains. One millilitre of prepared suspension of B. subtilis

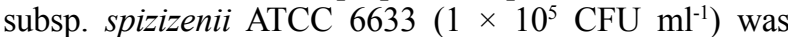
added to $10 \mathrm{ml}$ of the medium, melted before and cooled to $45^{\circ} \mathrm{C}$ and was mixed thoroughly. The prepared mixture of bacteria cell suspension and the medium were poured into $90 \mathrm{~mm}$ Petri dishes. After the medium had solidified and agar surface had dried, wells of $8 \mathrm{~mm}$ diameter were made in the plates and filled with $50 \mu \mathrm{l}$ of lactic acid bacteria cultures solution. Antimicrobial effect against the bacteria cultures was evaluated after $24 \mathrm{~h}$ of growth (at the optimal temperature) according to the diameter of inhibition zones (in $\mathrm{mm}$ ) around the wells. If inhibition zones failed to form around wells, the test solution had no antimicrobial effect against the tested bacteria culture.

The antimicrobial activity of supernatants from lactic acid bacteria cultures: Lactococcus lactis subsp. lactis 140/3, Lactobacillus plantarum, L. casei subsp. casei, L. acidophilus 336, L. helveticus, L. delbrueckii subsp. bulgaricus 148/3, L. brevis and L. bifidum grown in MRS (De Man, Rogosa and Sharpe) ("Oxoid", England) broth at $32^{\circ} \mathrm{C}$ for $16 \mathrm{~h}$ was determined by an agar well diffusion assay. Supernatants were obtained by centrifugation of cultures at $10,000 \mathrm{~g}$ at $4^{\circ} \mathrm{C}$ for $10 \mathrm{~min}$, adjusted to $\mathrm{pH} 6.2$ with $1 \mathrm{moll}^{-1} \mathrm{NaOH}$, sterilized through $0.22 \mu \mathrm{m}$ pore-size (Millipore Corp., USA) and stored at $20^{\circ} \mathrm{C}$ until use. $50 \mu \mathrm{l}$ aliquots of cell-free culture supernatants were poured into wells of $8-\mathrm{mm}$ diameter cut in the solidified PCA agar plates previously inoculated $(1 \times$
$10^{5} \mathrm{CFU} \mathrm{ml^{-1 }}$ ) with spores of $B$. subtilis subsp. spizizenii ATCC 6633. After $2 \mathrm{~h}$ at $4^{\circ} \mathrm{C}$, the plates were incubated at $30^{\circ} \mathrm{C}$ temperature for 3 days. Then the antimicrobial activity of lactic acid bacteria was evaluated according to the clear zones formed around the well. The size of the clear zone indicated the sensitivity of the B. subtilis subsp. spizizenii ATCC 6633 to the tested lactic acid bacteria culture. The width of the growth-inhibition zone was measured using sliding calipers. After measuring the total diameter and excluding the diameter of the well, the width of the inhibition zone was calculated using the following formula:

$$
H=\frac{D-d}{2} \text {, where } \mathrm{H} \text { is the width of the }
$$

inhibition zone, $\mathrm{mm}, \mathrm{D}$ - the total diameter of the sterile zone and the circle, $\mathrm{mm}, \mathrm{d}-$ the diameter of the well, $\mathrm{mm}$.

The lactic acid bacteria cultures with the highest antimicrobial activity were used for fermentation of wheat bread dough contaminated by spore-forming bacteria. Ropiness appearance was evaluated in the baked bread during 5 days storage at $18 \pm 2$ and $30 \pm 2{ }^{\circ} \mathrm{C}$.

Analysis of data. All tests were repeated three times. Data in all tables are presented as number of $\mathrm{CFU} \mathrm{g}^{-1}$ except Table 2 (last column) and Table 3 where data are presented as mean and standard deviation. The distribution of the count of spore forming aerobic bacteria in different points of bread dough is compared by using Chi square test for quality of probabilities. The difference was considered as statistically significant if $\mathrm{p}$ value $<0.05$

\section{Results}

Bread dough samples were contaminated by aerobic spore-forming bacteria using three different methods: spore suspension was added to the dough, to the mixture of dry raw materials and to the liquid phase of the dough. The results of the study are presented in Table 2.

Table 2. Aerobic spore-forming bacteria count in bread dough for three different methods of sample contamination

\begin{tabular}{|c|c|c|c|c|c|c|}
\hline \multirow[t]{2}{*}{ Methods of sample contamination } & \multicolumn{4}{|c|}{$\begin{array}{l}\text { Count of spore-forming aerobic bacteria } \\
\text { in the different points of bread dough } \\
\qquad \text { CFU g-1 }\end{array}$} & \multirow[t]{2}{*}{$\begin{array}{l}\text { Assessment of the } \\
\text { uniformity of distribution } \\
\text { CFU g g }\end{array}$} & \multirow[t]{2}{*}{$p$-value } \\
\hline & A & $\mathrm{B}$ & $\mathrm{C}$ & $\mathrm{D}$ & & \\
\hline $\begin{array}{l}\text { Spore suspension added } \\
\text { to the dough }\end{array}$ & $5.9 \times 10^{3}$ & $1.1 \times 10^{4}$ & $1.4 \times 10^{4}$ & $2.7 \times 10^{4}$ & $(7.5 \pm 1.3) \times 10^{4}$ & $<0.001$ \\
\hline $\begin{array}{l}\text { Spore suspension added } \\
\text { to the mixture of dry raw materials }\end{array}$ & $3.9 \times 10^{2}$ & $4.9 \times 10^{2}$ & $1.5 \times 10^{2}$ & $7.9 \times 10^{1}$ & $(2.8 \pm 1.9) \times 10^{2}$ & $<0.001$ \\
\hline $\begin{array}{l}\text { Spore suspension added } \\
\text { to the liquid phase of the dough }\end{array}$ & $1.4 \times 10^{4}$ & $1.1 \times 10^{4}$ & $1.9 \times 10^{4}$ & $1.4 \times 10^{4}$ & $(1.5 \pm 0.3) \times 10^{4}$ & $>0.05$ \\
\hline
\end{tabular}

$\mathrm{A}$ - point in the cross-section of semi-product, at the point of height and width inter-section; $\mathrm{B}$ - point in the higher part (close to the surface) of the cross-section of semi-product; $\mathrm{C}$ and $\mathrm{D}$ - at random points of the longitudinal section line of the semi-product

The comparison of different methods of contamination by spore-forming bacteria showed that the homogeneity of distribution of these bacteria in bread dough differed. It was found that the spore suspension was distributed most evenly in the bread dough when added to a liquid dough phase: an average value of the sporeforming aerobic bacteria count was $(1.5 \pm 0.3) \times 10^{4} \mathrm{CFU}$ $\mathrm{g}^{-1}$. For further studies, this method of contaminating was chosen. Technological characteristics of bread (control and test samples, contaminated by different counts of aerobic spore-forming bacteria) were determined after wheat bread baking tests, i.e. $6 \mathrm{~h}$ after baking (Table 3 ).

It was found that the technological characteristics of the control and test samples differed insignificantly. 
Table 3. Evaluation of the technological characteristics of bread quality

\begin{tabular}{cccc}
\hline \multirow{2}{*}{ Samples } & \multicolumn{3}{c}{ Technological characteristics } \\
\cline { 2 - 4 } & Moisture \% & Acidity ${ }^{\circ} \mathrm{N}$ & Porosity \% \\
\hline Control & $48.5 \pm 1.7$ & $5.4 \pm 0.1$ & $67.4 \pm 1.4$ \\
$\mathrm{~T}-1$ & $48.8 \pm 0.9$ & $5.6 \pm 0.1$ & $65.4 \pm 2.7$ \\
$\mathrm{~T}-2$ & $49.6 \pm 0.4$ & $5.5 \pm 0.2$ & $64.9 \pm 2.1$ \\
$\mathrm{~T}-3$ & $49.8 \pm 2.0$ & $5.5 \pm 0.1$ & $65.7 \pm 0.9$ \\
\hline
\end{tabular}

$\mathrm{T}-1$ - the sample contaminated by $12 \mathrm{ml}\left(1.4 \times 10^{4} \mathrm{CFU} \mathrm{ml}^{-}\right.$ $\left.{ }^{1}\right)$ of spore suspension; T-2 - the sample contaminated by $12 \mathrm{ml}\left(2.8 \times 10^{6} \mathrm{CFU} \mathrm{\textrm {ml } ^ { - 1 }}\right)$ of spore suspension; T-3 - the sample contaminated by $12 \mathrm{ml}\left(1.0 \times 10^{8} \mathrm{CFU} \mathrm{ml}^{-1}\right)$ of spore suspension
This indicates that the contamination of the test samples by aerobic spore-forming bacteria in the initial storage phase ( $6 \mathrm{~h}$ after baking) did not affect the quality of wheat bread. During the storage of bread, the occurrence of ropiness defect was observed every day and the amount of aerobic spore-forming bacteria was determined. The results of the study on the ropiness defect in bread samples, contaminated by different amounts of spore suspensions $\left(1.4 \times 10^{4}, 2.8 \times 10^{6}\right.$ and $\left.1.0 \times 10^{8} \mathrm{CFU} \mathrm{ml}^{-1}\right)$ are presented in Tables $4-6$.

No ropiness was observed in the samples of bread, whose dough was contaminated by different amounts of spore suspension $\left(1.4 \times 10^{4} \mathrm{CFU} \mathrm{ml}^{-1}\right)$, stored from 1 to 5 days.

Table 4. Signs of ropiness defect in bread samples contaminated by different amounts of spore suspension $\left(1.4 \times 10^{4}\right.$

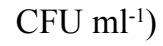

\begin{tabular}{|c|c|c|c|c|c|c|c|}
\hline \multirow{3}{*}{$\begin{array}{c}\text { Amount of } \\
\text { spore suspension } \\
\text { for contamination } \\
\text { of sample ml }\end{array}$} & \multirow{3}{*}{$\begin{array}{c}\text { Temperature } \\
\text { of bread } \\
\text { storage } \\
{ }^{\circ} \mathrm{C}\end{array}$} & \multicolumn{3}{|c|}{$\begin{array}{l}\text { Appearance of signs } \\
\text { of the ropiness defect }\end{array}$} & \multicolumn{3}{|c|}{$\begin{array}{l}\text { Aerobic spore-forming bacteria count } \\
\text { in bread samples, } \mathrm{CFU} \mathrm{g} \mathrm{g}^{-1}\end{array}$} \\
\hline & & \multicolumn{3}{|c|}{ storage of bread, days } & \multicolumn{3}{|c|}{ storage of bread, days } \\
\hline & & 1 & 3 & 5 & 1 & 3 & 5 \\
\hline \multirow{3}{*}{0} & $2 \pm 2$ & - & - & - & $2.0 \times 10^{0}$ & $7.0 \times 10^{1}$ & $1.4 \times 10^{2}$ \\
\hline & $18 \pm 2$ & - & - & - & $2.2 \times 10^{0}$ & $8.4 \times 10^{1}$ & $2.1 \times 10^{2}$ \\
\hline & $30 \pm 2$ & - & - & - & $2.2 \times 10^{0}$ & $9.3 \times 10^{1}$ & $2.6 \times 10^{2}$ \\
\hline \multirow{3}{*}{4} & $2 \pm 2$ & - & - & - & $3.0 \times 10^{0}$ & $2.2 \times 10^{2}$ & $9.7 \times 10^{2}$ \\
\hline & $18 \pm 2$ & - & - & - & $4.0 \times 10^{0}$ & $2.5 \times 10^{2}$ & $9.7 \times 10^{2}$ \\
\hline & $30 \pm 2$ & - & - & - & $4.0 \times 10^{0}$ & $2.5 \times 10^{2}$ & $9.7 \times 10^{2}$ \\
\hline \multirow{3}{*}{8} & $2 \pm 2$ & - & - & - & $4.4 \times 10^{1}$ & $7.0 \times 10^{2}$ & $1.5 \times 10^{3}$ \\
\hline & $18 \pm 2$ & - & - & - & $5.1 \times 10^{1}$ & $7.1 \times 10^{2}$ & $1.5 \times 10^{3}$ \\
\hline & $30 \pm 2$ & - & - & - & $5.8 \times 10^{1}$ & $7.9 \times 10^{2}$ & $1.5 \times 10^{3}$ \\
\hline \multirow{3}{*}{12} & $2 \pm 2$ & - & - & - & $5.7 \times 10^{1}$ & $2.0 \times 10^{2}$ & $4.8 \times 10^{3}$ \\
\hline & $18 \pm 2$ & - & - & - & $6.1 \times 10^{1}$ & $2.4 \times 10^{2}$ & $2.6 \times 10^{4}$ \\
\hline & $30 \pm 2$ & - & - & - & $5.9 \times 10^{1}$ & $2.8 \times 10^{2}$ & $3.3 \times 10^{4}$ \\
\hline
\end{tabular}

Table 5. Signs of ropiness defect in bread samples contaminated by different amounts of spore suspension $\left(2.8 \times 10^{6}\right.$ CFU ml-1)

\begin{tabular}{|c|c|c|c|c|c|c|c|}
\hline \multirow{3}{*}{$\begin{array}{c}\text { Amount of } \\
\text { spore suspension } \\
\text { for contamination } \\
\text { of sample } \mathrm{ml}\end{array}$} & \multirow{3}{*}{$\begin{array}{c}\text { Temperature } \\
\text { of bread } \\
\text { storage } \\
{ }^{\circ} \mathrm{C}\end{array}$} & \multicolumn{3}{|c|}{$\begin{array}{c}\text { Appearance of signs } \\
\text { of ropiness defect }\end{array}$} & \multicolumn{3}{|c|}{$\begin{array}{l}\text { Aerobic spore-forming bacteria count } \\
\text { in bread samples, CFU g }{ }^{-1}\end{array}$} \\
\hline & & \multicolumn{3}{|c|}{ storage of bread, days } & \multicolumn{3}{|c|}{ storage of bread, days } \\
\hline & & 1 & 3 & 5 & 1 & 3 & 5 \\
\hline \multirow{3}{*}{0} & $2 \pm 2$ & - & - & - & $4.0 \times 10^{0}$ & $6.8 \times 10^{1}$ & $3.0 \times 10^{2}$ \\
\hline & $18 \pm 2$ & - & - & - & $4.6 \times 10^{0}$ & $7.3 \times 10^{1}$ & $5.1 \times 10^{2}$ \\
\hline & $30 \pm 2$ & - & - & - & $5.2 \times 10^{0}$ & $8.7 \times 10^{1}$ & $5.6 \times 10^{2}$ \\
\hline \multirow{3}{*}{4} & $2 \pm 2$ & - & - & - & $7.1 \times 10^{1}$ & $1.2 \times 10^{3}$ & $1.6 \times 10^{3}$ \\
\hline & $18 \pm 2$ & - & - & - & $7.4 \times 10^{1}$ & $3.2 \times 10^{3}$ & $3.0 \times 10^{3}$ \\
\hline & $30 \pm 2$ & - & - & - & $8.0 \times 10^{1}$ & $4.0 \times 10^{3}$ & $3.0 \times 10^{3}$ \\
\hline \multirow{3}{*}{8} & $2 \pm 2$ & - & - & - & $2.1 \times 10^{1}$ & $7.7 \times 10^{3}$ & $1.0 \times 10^{4}$ \\
\hline & $18 \pm 2$ & - & - & - & $4.0 \times 10^{1}$ & $6.2 \times 10^{3}$ & $1.6 \times 10^{4}$ \\
\hline & $30 \pm 2$ & - & $+*$ & $++* *$ & $5.3 \times 10^{1}$ & $4.4 \times 10^{5}$ & $1.2 \times 10^{6}$ \\
\hline \multirow{3}{*}{12} & $2 \pm 2$ & - & - & - & $1.9 \times 10^{1}$ & $7.1 \times 10^{2}$ & $4.7 \times 10^{4}$ \\
\hline & $18 \pm 2$ & - & ++ & $+++* * *$ & $2.1 \times 10^{2}$ & $2.0 \times 10^{6}$ & $1.2 \times 10^{7}$ \\
\hline & $30 \pm 2$ & - & ++ & +++ & $6.0 \times 10^{2}$ & $2.5 \times 10^{6}$ & $1.5 \times 10^{7}$ \\
\hline
\end{tabular}

* - weak signs of ropiness spoilage (slight rope): faint odour, little mucus isolated, random black spots; $* *$ medium signs of ropiness spoilage (moderate rope): well perceptible odour, mucus on the surface of the pulp cover more than half cross-sectional area, brown and reddish spots; *** - distinct signs of ropiness spoilage (advanced rope): strong odor, much mucus of the pulp, reddish and purple spots 
Table 6. Signs of ropiness defect in bread samples contaminated by different amounts of spore suspension $\left(1.0 \times 10^{8}\right.$ CFU ml-1)

\begin{tabular}{|c|c|c|c|c|c|c|c|}
\hline \multirow{3}{*}{$\begin{array}{l}\text { Amount of } \\
\text { spore suspension } \\
\text { for contamination } \\
\text { of sample ml }\end{array}$} & \multirow{3}{*}{$\begin{array}{c}\text { Temperature of } \\
\text { bread storage } \\
{ }^{\circ} \mathrm{C}\end{array}$} & \multicolumn{3}{|c|}{$\begin{array}{l}\text { Appearance of signs } \\
\text { of the ropiness defect }\end{array}$} & \multicolumn{3}{|c|}{ 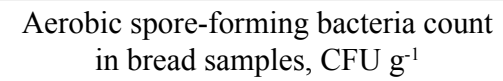 } \\
\hline & & \multicolumn{3}{|c|}{ storage of bread, days } & \multicolumn{3}{|c|}{ storage of bread, days } \\
\hline & & 1 & 3 & 5 & 1 & 3 & 5 \\
\hline \multirow{3}{*}{0} & $2 \pm 2$ & - & - & - & $2.0 \times 10^{0}$ & $4.0 \times 10^{1}$ & $7.6 \times 10^{2}$ \\
\hline & $18 \pm 2$ & - & - & - & $3.5 \times 10^{0}$ & $4.8 \times 10^{1}$ & $7.4 \times 10^{2}$ \\
\hline & $30 \pm 2$ & - & - & - & $3.8 \times 10^{0}$ & $4.8 \times 10^{1}$ & $6.9 \times 10^{2}$ \\
\hline \multirow{3}{*}{4} & $2 \pm 2$ & - & - & - & $1.7 \times 10^{2}$ & $6.4 \times 10^{2}$ & $1.9 \times 10^{3}$ \\
\hline & $18 \pm 2$ & + & ++ & +++ & $3.2 \times 10^{5}$ & $1.3 \times 10^{6}$ & $9.1 \times 10^{7}$ \\
\hline & $30 \pm 2$ & ++ & +++ & $++++*$ & $6.0 \times 10^{6}$ & $8.3 \times 10^{7}$ & $2.2 \times 10^{8}$ \\
\hline \multirow{3}{*}{8} & $2 \pm 2$ & - & + & ++ & $2.1 \times 10^{5}$ & $4.5 \times 10^{6}$ & $3.8 \times 10^{7}$ \\
\hline & $18 \pm 2$ & + & ++ & +++ & $5.9 \times 10^{5}$ & $2.0 \times 10^{7}$ & $1.2 \times 10^{8}$ \\
\hline & $30 \pm 2$ & ++ & +++ & ++++ & $4.9 \times 10^{7}$ & $3.8 \times 10^{8}$ & $7.8 \times 10^{8}$ \\
\hline \multirow{3}{*}{12} & $2 \pm 2$ & - & ++ & +++ & $8.3 \times 10^{5}$ & $7.8 \times 10^{6}$ & $6.1 \times 10^{7}$ \\
\hline & $18 \pm 2$ & + & ++ & +++ & $1.0 \times 10^{6}$ & $1.1 \times 10^{8}$ & $4.3 \times 10^{8}$ \\
\hline & $30 \pm 2$ & ++ & +++ & ++++ & $1.4 \times 10^{8}$ & $6.3 \times 10^{8}$ & $1.8 \times 10^{9}$ \\
\hline
\end{tabular}

* - very strong signs of ropiness defect (very advanced rope): distinct odour, the area of the cross-section is mucous, with bright purple spots

Samples contaminated by an average amount $(8 \mathrm{ml})$ of spore suspension and stored at $30 \pm 2^{\circ} \mathrm{C}$ showed weak signs of ropiness spoilage, which began to appear on the $3^{\text {rd }}$ day $\left(\mathrm{N}=4.4 \times 10^{5} \mathrm{CFU} \mathrm{g}^{-1}\right)$, while on the $5^{\text {th }}$ day, these signs were evaluated as moderate rope symptoms $\left(\mathrm{N}=1.2 \times 10^{6} \mathrm{CFU} \mathrm{g}^{-1}\right)$. The defects of ropiness increased after contamination of the samples with $12 \mathrm{ml}$ of spore suspension: moderate rope symptoms appeared on the $3^{\text {rd }}$ day $\left(\mathrm{N}=2.5 \times 10^{6} \mathrm{CFU} \mathrm{g}{ }^{-1}\right)$, advanced rope symptoms, on the $5^{\text {th }}$ day $\left(\mathrm{N}=1.5 \times 10^{7} \mathrm{CFU} \mathrm{g}^{-1}\right)$. The results showed that during the storage of bread samples for 3 days previously contaminated by $12 \mathrm{ml}$ of spore suspension at $18 \pm 2{ }^{\circ} \mathrm{C}$, the number of aerobic bacteria increased up to $2.0 \times 10^{6} \mathrm{CFU} \mathrm{\textrm {g } ^ { - 1 }}$ and moderate rope symptoms appeared, although the storage of samples was 5 days $(\mathrm{N}$ $\left.=1.2 \times 10^{7} \mathrm{CFU} \mathrm{g}^{-1}\right)$. In other cases of the study, the signs of ropiness defect did not appear in the bread samples contaminated by different amounts of spore suspension $\left(\mathrm{N}=2.8 \times 10^{6} \mathrm{CFU} \mathrm{ml}^{-1}\right)$ and kept from 1 to 5 days.

The data suggest that after contamination of bread samples with $1.0 \times 10^{8} \mathrm{CFU} \mathrm{ml}^{-1}$ spore suspension, the signs of ropiness appeared already from the first day of storage: weak signs at $18 \pm 2{ }^{\circ} \mathrm{C}$, medium signs at 30 $\pm 2^{\circ} \mathrm{C}$. During the storage of samples at $2 \pm 2{ }^{\circ} \mathrm{C}$, weak and medium signs of ropiness appeared on the $3^{\text {rd }}$ day of storage, depending on the amount of spore suspension. It was found that during the storage of samples for up to 5 days, the number of spore-forming aerobic bacteria increased evenly and the signs of ropiness were more intensive as the storage temperature increased. Prominent signs of ropiness defect appeared on the $5^{\text {th }}$ day of storage of samples at $18 \pm 2^{\circ} \mathrm{C}\left(\mathrm{N}=9.1 \times 10^{7} \div 4.3 \times 10^{8} \mathrm{CFU} \mathrm{g}^{-1}\right)$, or on the $3^{\text {rd }}$ day at $30 \pm 2{ }^{\circ} \mathrm{C}\left(\mathrm{N}=8.3 \times 10^{7} \div 6.3 \times 10^{8}\right.$ $\left.\mathrm{CFU} \mathrm{^{-1 }}\right)$; very distinctive signs appeared on the $5^{\text {th }}$ day at $30 \pm 2{ }^{\circ} \mathrm{C}\left(\mathrm{N}=2.2 \times 10^{8} \div 1.8 \times 10^{9} \mathrm{CFU} \mathrm{g}^{-1}\right)$.

The antimicrobial activity of supernatants from lactic acid bacteria cultures: Lactococcus lactis subsp. lactis 140/3, Lactobacillus plantarum, L. casei subsp. casei, L. acidophilus 336, L. helveticus, L. delbrueckii subsp. bulgaricus 148/3, L. brevis and L. bifidum was determined by an agar well diffusion assay. Antimicrobial activity of Lactococcus and Lactobacillus against aerobic spore-forming bacteria was different. L. delbrueckii subsp. bulgaricus $\left(2.7 \times 10^{7} \mathrm{CFU} \mathrm{ml}^{-1}\right)$, L. acidophilus $(1.0 \times$ $\left.10^{5} \mathrm{CFU} \mathrm{ml}^{-1}\right)$, L. casei subsp. casei $\left(4.1 \times 10^{7} \mathrm{CFU} \mathrm{ml}^{-1}\right)$ showed the highest antimicrobial activity - diameter of inhibition zone was from $5.8 \pm 0.3$ to $7.5 \pm 1.3 \mathrm{~mm}$ (Fig.). Lactococcus lactis subsp. lactis 140/2 $\left(3.2 \times 10^{9} \mathrm{CFU}\right.$ $\left.\mathrm{ml}^{-1}\right)$, Lactobacillus bifidum $\left(1.1 \times 10^{9} \mathrm{CFU} \mathrm{ml}{ }^{-1}\right)$ and $L$. helveticus $\left(1.0 \times 10^{5} \mathrm{CFU} \mathrm{ml}^{-1}\right)$ was characterized by low (medium) antimicrobial activity against aerobic sporeforming bacteria (diameter of inhibition zone was $<4.8$ $\mathrm{mm})$. L. plantarum $\left(1.1 \times 10^{8} \mathrm{CFU} \mathrm{ml}^{-1}\right)$ and L. brevis $\left(1.0 \times 10^{5} \mathrm{CFU} \mathrm{ml}^{-1}\right)$ had no effect against aerobic sporeforming bacteria (diameter of inhibition zone was from $1.3 \pm 0.5$ to $1.0 \pm 0.0 \mathrm{~mm}$ ).

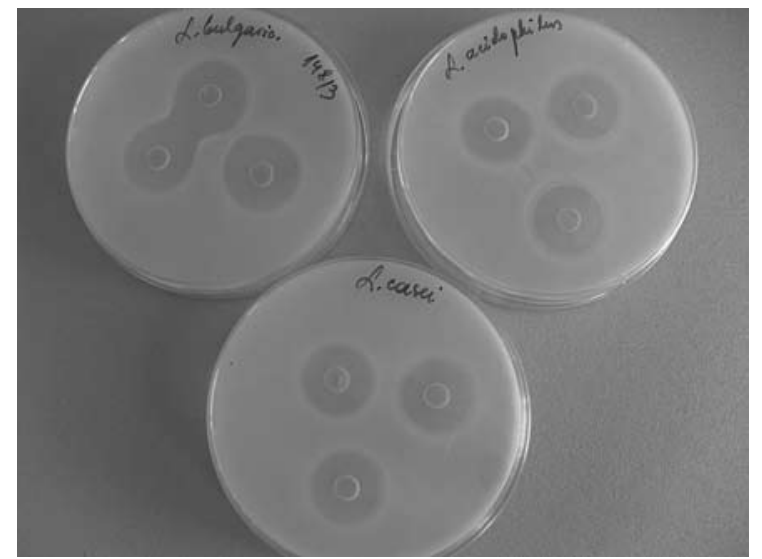

Figure. Antimicrobial effect of supernatants from Lactobacillus delbrueckii subsp. bulgaricus, L. acidophilus, L. casei subsp. casei 
Wheat bread dough samples (contaminated

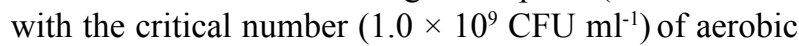
spore-forming bacteria Bacillus subtilis subsp. spizizenii ATCC 6633) were fermented with the lactic acid bacteria characterized by the highest antimicrobial activity against aerobic spore-forming bacteria and the signs of ropiness in the baked bread were observed. It was found that the technological characteristics of bread dough samples in the initial stage of storage ( $6 \mathrm{~h}$ after baking) were complying with the regulatory requirements: pulp moisture $-49.7 \pm 0.4 \%, \mathrm{pH}-5.1 \pm 0.2$ on, porosity -71.8 $\pm 1.2 \%$. In wheat bread samples, that had been fermented with lactic acid bacteria, the antimicrobial effects were observed at $18^{\circ} \mathrm{C}$ and $30^{\circ} \mathrm{C}$ temperature for up to 3 days of storage. Signs of ropiness were very weak during the storage of bread samples at $18 \pm 2{ }^{\circ} \mathrm{C}$ for 5 days $\left(1.7 \times 10^{2}\right.$ $\left.\mathrm{CFU} \mathrm{g^{-1 }}\right)$ and during the storage at $30 \pm 2{ }^{\circ} \mathrm{C}$ temperature for 3 and 5 days $\left(1.5 \times 10^{2} \mathrm{CFU} \mathrm{g}^{-1}\right)$.

\section{Discussion}

The data suggest that after contamination of dough samples by $B$. subtilis subsp. spizizenii ATCC 6633 4-12 $\mathrm{ml}^{1.0} \times 10^{8} \mathrm{CFU} \mathrm{g}^{-1}$ (Table 6), the signs of ropiness (rotting smell, sliming of the pulp, coloured spots) appeared already from the first day of storage: slight rope at $18 \pm 2{ }^{\circ} \mathrm{C}$, moderate rope at $30 \pm 2^{\circ} \mathrm{C}$. During the storage of samples at $2 \pm 2{ }^{\circ} \mathrm{C}$, moderate rope appeared on the $3^{\text {rd }}$ day of storage, depending on the level of contamination. The results of the research showed that during the storage of bread for up to 5 days, the number of spore-forming bacteria was still increasing evenly and the signs of ropiness became more intensive with increasing of storage temperature (Tables 6-5).

It was found that in the samples kept at a cooling temperature $2 \pm 2^{\circ} \mathrm{C}$ (concentration of contamination 8.0 $\left.\times 10^{8} \mathrm{CFU} \mathrm{g}^{-1}\right)$, the initial signs of ropiness appeared on the $3^{\text {rd }}$ day (in the bread samples $\mathrm{N}=4.5 \times 10^{6} \div 7.8 \times$ $10^{6} \mathrm{CFU} \mathrm{g}^{-1}$ ), these signs were more prominent on the $5^{\text {th }}$ day $-\mathrm{N}=3.8 \times 10^{7} \div 6.1 \times 10^{7} \mathrm{CFU} \mathrm{g}^{-1}$ (concentration of contamination $1.2 \times 10^{9} \mathrm{CFU} \mathrm{g}^{-1}$ ) (Table 6).

Keeping the bread samples at bread consumption temperature $18 \pm 2^{\circ} \mathrm{C}$, the initial signs of ropiness were observed after one day and increased from $3.2 \times 10^{5}$ to $1.0 \times 10^{6} \mathrm{CFU} \mathrm{g}^{-1}$ (concentration of contamination $4.0 \times$ $10^{8}$ and $1.2 \times 10^{9} \mathrm{CFU} \mathrm{g}^{-1}$ ). In other cases (at $18 \pm 2^{\circ} \mathrm{C}$ ) of the research, the slight rope appeared on the $3^{\text {rd }}$ day $\mathrm{N}=1.3 \times 10^{6} \div 2.0 \times 10^{7} \mathrm{CFU} \mathrm{g}^{-1}$, and increased during storage: on the $5^{\text {th }}$ day, the number of spore-forming bacteria in the samples increased $\mathrm{N}=1.2 \times 10^{7} \div 4.3 \times$ $10^{8} \mathrm{CFU} \mathrm{g}^{-1}$ (Tables 5-6). Experimental data suggest that the signs of ropiness in the bread samples appeared at 30 $\pm 2^{\circ} \mathrm{C}$ after one day of storage $\left(\mathrm{N}=6.0 \times 10^{6} \mathrm{CFU} \mathrm{g}^{-1}\right)$ and increased with the increasing degree of contamination. Very advanced rope appeared at $30 \pm 2^{\circ} \mathrm{C}$ in the bread samples on the $3^{\text {rd }}-5^{\text {th }}$ day of storage $-\mathrm{N}=8.3 \times 10^{7} \div 1.8$ $\times 10^{9} \mathrm{CFU} \mathrm{g}^{-1}$ (Table 6).

The critical levels of aerobic spore-forming bacteria, causing ropiness were determined: 1) $7.8 \times 10^{6}$ $\mathrm{CFU} \mathrm{g^{-1 }}$ after storage of samples for 3 days at $2 \pm 2{ }^{\circ} \mathrm{C}$,
2) $1.3 \times 10^{6} \mathrm{CFU} \mathrm{g}^{-1}$ after storage of samples for 3 days at $18 \pm 2^{\circ} \mathrm{C}$ and 3) $6.0 \times 10^{6} \mathrm{CFU} \mathrm{g}^{-1}$ after storage of samples for 1 day at $30 \pm 2{ }^{\circ} \mathrm{C}$.

Theresultsofthisstudyshowed thatcontamination of dough by aerobic spore-forming bacteria should be not higher than $1.0 \times 10^{3} \mathrm{CFU} \mathrm{g}^{-1}$. The study also showed that the technological characteristics of bread dough samples (contaminated with the critical number of aerobic sporeforming bacteria $B$. subtilis subsp. spizizenii ATCC 6633 ) fermented with lactic acid bacteria characterized by the highest antimicrobial activity against aerobic spore-forming bacteria: Lactobacillus delbrueckii subsp. bulgaricus, L. acidophilus and L. casei subsp. casei in the initial stage of storage ( $6 \mathrm{~h}$ after baking) complied with the regulatory requirements: pulp moisture -49.7 $\pm 0.4 \%, \mathrm{pH}-5.1 \pm 0.2$ on, porosity $-71.8 \pm 1.2 \%$. In wheat bread samples, that had been fermented with lactic acid bacteria, characterized by the highest antimicrobial activity, the antimicrobial effects were observed at $18^{\circ} \mathrm{C}$ and $30^{\circ} \mathrm{C}$ temperature for up to 3 days of storage. Signs of ropiness were very weak during the storage of bread samples at $18 \pm 2{ }^{\circ} \mathrm{C}$ temperature for 5 days $\left(1.7 \times 10^{2}\right.$

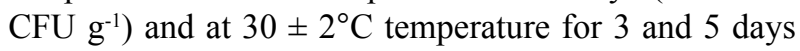
$\left(1.5 \times 10^{2} \mathrm{CFU} \mathrm{g}^{-1}\right)$.

\section{Conclusions}

1. Cereal grain and all types of wheat flour are usually contaminated with Bacillus spores from the environment. These spores may cause problems in bakeries, and one of the main defects of contaminated bread is ropiness.

2. The signs of ropiness appeared on the first day after contamination of dough samples by Bacillus subtilis subsp. spizizenii ATCC $6633\left(4.0 \times 10^{8}-1.2 \times 10^{9} \mathrm{CFU}\right.$ $\left.\mathrm{g}^{-1}\right)$ : slight rope appeared at $18 \pm 2{ }^{\circ} \mathrm{C}$, moderate rope at $30 \pm 2^{\circ} \mathrm{C}$ temperature. During the storage of bread at $2 \pm 2^{\circ} \mathrm{C}$, moderate rope appeared on the $3^{\text {rd }}$ day of storage. Consequently the number of spore-forming aerobic bacteria during the storage of bread for up to 5 days was still increasing evenly and the signs of ropiness increased with increasing of the storage temperature.

3. Lactic acid bacteria Lactobacillus delbrueckii subsp. bulgaricus, L. acidophilus and L. casei subsp. casei showed the highest antimicrobial activity. Very weak signs of ropiness were observed at $18^{\circ} \mathrm{C}$ and $30^{\circ} \mathrm{C}$ temperature for up to 3 days of bread storage: the amount of aerobic spore-forming bacteria was as low as $1.7 \times 10^{2}$ $\mathrm{CFU} \mathrm{g^{-1 }}$ during the storage of bread samples at $18 \pm 2^{\circ} \mathrm{C}$ for 5 days, and $1.5 \times 10^{2} \mathrm{CFU} \mathrm{g}^{-1}$ during the storage at 30 $\pm 2^{\circ} \mathrm{C}$ for 3 and 5 days.

Received 03122014 Accepted 07072015

\section{References}

Aydin A., Paulsen P., Smulders J. M. 2009. The physicochemical and microbiological properties of wheat flour in Thrace. Turkish Journal of Agriculture and Forestry, 33: $445-454$ 
Blackburn de C. W. (ed.) 2006. Food spoilage microorganisms ( $1^{\text {st }}$ ed.)

Bredholt S., Nesbakken T., Holck A. 2001. Industrial application of an antilisterial strain of Lactobacillus sakei as a protective culture and its effect on the sensory acceptability of cooked, sliced, vacuum-packaged meats. International Journal of Food Microbiology, 66: 191-196

Brul S., van Beilen J., Caspers M., O'Brien A., de Koster C., Oomes S., Smelt J., Kort R., Beek A. T. 2011. Challenges and advances in systems biology analysis of Bacillus spore physiology; molecular differences between an extreme heat resistant spore forming Bacillus subtilis food isolate and a laboratory strain. Food Microbiology, 28: 221-227

Caplice E., Fitzgerald G. F. 1999. Food fermentations: role of microorganisms in food production and preservation. International Journal of Food Microbiology, 50: 131-149

Cavalieri S. J., Hrabovsky S., Jorgensen T. 2005. Manual of antimicrobial susceptibility testing. American Society for Microbiology. Washington D.C., p. 220-221

Coloretti F., Chiavari C., Armaforte E., Carri S., Castagnetti G. B. 2008. Combined use of starter cultures and preservatives to control production of biogenic amines and improve sensorial profile in low-acid salami. Journal of Agricultural and Food Chemistry, 56 (23): 11238-11244 http://dx.doi.org/10.1021/jf802002z

Denkova R., Ilieva S., Denkova Z., Georgieva L., Krastanov A. 2014. Examination of the technological properties of newly isolated strains of the genus Lactobacillus and possibilities for their application in the composition of starters. Biotechnology and Biotechnological Equipment, 28 (3): 487-494

http://dx.doi.org/10.1080/13102818.2014.918701

Dewettinck K., Van Bockstaele F., Kühne B., Van de Walle D., Courtens T. M., Gellynck X. 2008. Nutritional value of bread: influence of processing, food interaction and consumer perception. Journal of Cereal Science, 48: 243-257

Fangio M. F., Roura S. I., Fritz R. 2010. Isolation and identification of Bacillus spp. and related genera from different starchy foods. Journal of Food Science, 75: 218-221

Gobbetti M., De Angelis M., Corsetti A., Di Cagno R. 2005. Biochemistry and physiology of sourdough lactic acid bacteria. Trends Food Science Technology Journal, 16: $57-69$

Hansen E. B. 2002. Commercial bacterial starter cultures for fermented foods of the future. International Journal of Food Microbiology, 78 (1-2): 119-131

Heyndrickx M. 2011. The importance of endospore-forming bacteria originating from soil for contamination of industrial food processing. Applied and Environmental Soil Science, 11: 1-11

Hladíková Z., Smetanková J., Greif G., Greifová M. 2012. Antimicrobial activity of selected lactic acid cocci and production of organic acids. Acta Chimica Slovaca, 5 (1): $80-85$ http://dx.doi.org/10.2478/v10188-012-0013-3

Iurlina M. O., Saiz A. I., Fuselli S. R., Fritz R. 2006. Prevalence of Bacillus spp. in different food products collected in Argentina. Food Science and Technology, 39 (2): 105-110 http://dx.doi.org/10.1016/j.lwt.2005.01.006

Kornacki J. L. 2010. Principles of microbiological troubleshooting in the industrial food processing environment, p. 1-156

Logan N. A., Halket G. 2011. Developments in the taxonomy of aerobic, endospore-forming bacteria. Logan N. A., Vos P. (eds.). Endospore-forming soil bacteria. Soil Biology, vol.
27, Berlin, Heidelberg, p. 1-29

McAuliffe O., Ross R. P., Hill C. 2001. Lantabiotics: structure, biosynthesis and mode of action. Federation of European Microbiological Societies Microbiology Reviews, 25: $285-308$

Mentes Ö., Ercan R., Akçelik M. 2007. Inhibitor activities of two Lactobacillus strains, isolated from sourdough, against rope-forming Bacillus strains. Food Control, 18 (4): $359-363$ http://dx.doi.org/10.1016/j.foodcont.2005.10.020

Needham R., Williams J., Beales N., Voysey P., Magan N. 2005. Early detection and differentiation of spoilage of bakery products. Sensors and Actuators B, 106: 20-23

Piard J. C., Desmazeaud M. 1992. Inhibiting factors produced by lactic acid bacteria. 2. Bacteriocins and other antimicrobial substances. Lait, 72: 13-142

Rosenkvist H., Hansen A. 1995. Contamination profiles and characterization of Bacillus species in wheat bread and raw materials for bread production. International Journal of Food Microbiology, 26: 353-363

Ross R. P., Morgan S., Hill C. 2002. Preservation and fermentation: past, present and future. International Journal of Food Microbiology, 79: 3-16

Sakalauskas S., Kačergius A., Janušauskaitė D., Čitavičius D. 2014. Bacteria with a broad-spectrum of antagonistic activity against pathogenic fungi of cereals. ZemdirbysteAgriculture, 101 (2): 185-192 http://dx.doi.org/10.13080/z-a.2014.101.024

Setlow P. 2005. Spores of Bacillus subtilis: their resistance to and killing by radiation, heat and chemicals. Journal of Applied Microbiology, 101 (2006): 514-525

Sorokulova I. B., Reva O. N., Smirnov V. V., Pinchuk I. V., Lapa S. V., Urdaci M. C. 2003. Genetic diversity and involvement in bread spoilage of Bacillus strains isolated from flour and ropy bread. Letters in Applied Microbiology, 37: $169-173$

Thompson J. M., Waites W. M., Dodd C. E. R. 1998. Detection of rope spoilage in bread caused by Bacillus species. Journal of Applied Microbiology, 85: 481-486

Valerio F., De Bellis P., Lonigro S. L., Visconti A., Lavermicocca P. 2008. Use of Lactobacillus plantarum fermentation products in bread-making to prevent Bacillus subtilis ropy spoilage. International Journal of Food Microbiology, 122: 328-332

Voysey P. A. 1989. Studies of rope in bread. Flour Milling and Baking Research Association (FMBRA) Bulletin, 4: $141-148$

Voysey P. A., Hammond J. C. 1993. Reduced additive breadmaking technology. Smith J. (ed.). Technology of reducedadditive foods. London, UK, p. 80-94

Zhang J.-L., Aziz M., Qiao Y., Han Q.-Q., Li J., Wang Y.-Q., Shen X., Wang S.-M., Paré P. W. 2014. Soil microbe Bacillus subtilis (GB03) induces biomass accumulation and salt tolerance with lower sodium accumulation in wheat. Crop and Pasture Science, 65: 423-427 
ISSN 1392-3196 / e-ISSN 2335-8947

Zemdirbyste-Agriculture, vol. 102, No. 3 (2015), p. 351-358

DOI 10.13080/z-a.2015.102.045

\title{
Užterštumo Bacillus genties bakterijomis įtaka kvietinès duonos kokybei ir saugai
}

\author{
L. Vaičiulytė-Funk ${ }^{1}$, R. Žvirdauskienè $\dot{1}^{1,2}$ J. Šalomskienè ${ }^{1}$, A. Šarkinas ${ }^{1}$
}

${ }^{1}$ Kauno technologijos universiteto Maisto institutas

${ }^{2}$ Lietuvos agrarinių ir miškų mokslų centro Žemdirbystès institutas

\section{Santrauka}

Tyrimų tikslas - kvietinėje duonoje nustatyti sporinių aerobinių bakterijų skaičių, sukeliantị mikrobiologinės kilmės ydą - vadinamają bulvinę ligą, ir ịvertinti pieno rūgšties bakterijų antimikrobinį poveikị sporinėms aerobinėms bakterijoms esant skirtingoms temperatūroms kvietinès duonos laikymo metu.

Siekiant kontroliuoti gleivejjimo ydos plitimą kvietiniuose kepiniuose, tirtas ribinis sporinių aerobinių bakterijų Bacillus subtilis subsp. spizizenii ATCC 6633 skaičius, kvietinès duonos laikymo metu sukeliantis vadinamają bulvinę ligą. Šiuo tikslu parinktas užkrètimo aerobinėmis sporinėmis bakterijomis (Bacillus subtilis) būdas, atliktas iškeptų kvietinès duonos mėginių, kurių tešla prieš kepimą užkrèsta skirtingais kiekiais sporinių aerobinių bakterijų, mikrobiologinių ir technologinių kokybės rodiklių ịvertinimas gamybos ir laikymo metu. Nustatyti ribiniai sporinių aerobinių bakterijų kiekiai, kvietinès duonos laikymo metu sukeliantys vadinamają bulvinę ligą: $7,8 \times 10^{6} \mathrm{KSV}$ (kolonijas sudarantys vienetai) $\mathrm{g}^{-1}$, mèginius 3 paras laikant $2 \pm 2{ }^{\circ} \mathrm{C}$ temperatūroje, $1,3 \times 10^{6} \mathrm{KSV}$ $\mathrm{g}^{-1}$, mèginius 3 paras laikant $18 \pm 2{ }^{\circ} \mathrm{C}$ temperatūroje, ir $6,0 \times 10^{6} \mathrm{KSV} \mathrm{g}^{-1}$, mèginius 1 parą laikant $30 \pm 2{ }^{\circ} \mathrm{C}$ temperatūroje. Nustatyta, kad pradinis kvietinès duonos tešlos užteršimas sporinemis aerobinemis bakterijomis neturi viršyti $1,0 \times 10^{3} \mathrm{KSV} \mathrm{g}^{-1}$. Lactococcus ir Lactobacillus pieno rūgšties bakterijų antimikrobinis poveikis sporinėms aerobinėms bakterijoms tirtas difuzijos ị agarą būdu. Nustatyta, kad didžiausiu antimikrobiniu aktyvumu prieš sporines aerobines bakterijas pasižymėjo Lactobacillus delbrueckii subsp. bulgaricus 148/3, L. acidophilus 336 ir L. casei subsp. casei. Sporinèmis aerobinėmis bakterijomis užkrèsti kvietinės duonos pusgaminiai buvo fermentuoti pieno rūgšties bakterijomis, pasižymejjusiomis didžiausiu antimikrobiniu aktyvumu. Iškeptoje duonoje įvertintas vadinamosios bulvinès ligos požymių pasireiškimas per 5 paras, duonos mėginius laikant $18 \pm 2$ ir $30 \pm$ $2{ }^{\circ} \mathrm{C}$ temperatūroje. Bulvinès ligos požymiai (pakitęs kvapas ir minkštimo spalva) labai silpnai pasireiškè duonos mèginius 5 paras laikant $18 \pm 2{ }^{\circ} \mathrm{C}$ temperatūroje (sporinių aerobinių bakterijų kiekis $-1,7 \times 10^{2} \mathrm{KSV} \mathrm{g}^{-1}$ ) ir $3-5$ paras laikant $30 \pm 2{ }^{\circ} \mathrm{C}$ temperatūroje (sporinių aerobinių bakterijų kiekis $-1,5 \times 10^{2} \mathrm{KSV} \mathrm{g}^{-1}$ ).

Reikšminiai žodžiai: Bacillus subtilis, kvietinė duona, mikrobiologinès kilmès duonos ydos, pieno rūgšties bakterijos. 